\title{
DIREITO FUNDAMENTAL AO ACESSO À JUSTIÇA: CONTRADITÓRIO COOPERATIVO COMO FORMA DE EXPRESSÃO DA EFETIVA PRESTAÇÃO JURISDICIONAL
}

\author{
Donner Rodrigues Queiroz* \\ Luiz Carlos Figueira de Melo**
}

SUMÁRIO: Introdução; 2 Princípios Processuais Constitucionais; 3 O Princípio do Contraditório e sua Expressão Cooperativa como forma de Efetividade da Prestação Jurisdicional; 4 Considerações Finais; Referências.

RESUMO: O presente trabalho, a partir de análise teórico-jurídica e prática, buscará analisar o direito fundamental ao acesso à justiça sob a ótica do contraditório cooperativo, de modo a obter posicionamento acerca de sua importância para a efetiva prestação jurisdicional, à medida que consagra o dever de efetivo diálogo de todos os participantes no processo - partes e magistrado -, possibilitando, pois, que os litigantes influenciem, de modo direto e imediato, na construção das decisões judiciais, buscando-se a efetiva pacificação dos seus conflitos.

PALAVRA-CHAVE: Princípio; Contraditório; Cooperação; Prestação Jurisdicional e Acesso à Justiça.

\section{BASIC RIGHT TO ACCESS JUSTICE: COOPERATIVE CONTRADICTORY AS A T YPE OF EXPRESSION OF THE EFFECTIVE JURISDICTIONAL SERVICE}

\begin{abstract}
Fundamental right to access the courts from the point of view of cooperative contradictory is investigated through a theoretical and judicial analysis. Positioning on its importance is aimed for the effective jurisdictional service in so far as the right of effective dialogue of all the participants (magistrate and juridical parties) in the dialogue is guaranteed. The conflicting parties affect directly and immediately the construction of juridical decisions through the pacification of their conflicts.
\end{abstract}

KEY WORDS: Principle; Contradictory; Cooperation; Jurisdictional Service; Access to Courts.

\footnotetext{
Mestrando no Programa de Pós-Graduação em Educação pela Universidade de Uberaba (UNIUBE); Docente da Fundação Carmelita Mário Palmério (FACIHUS-FUCAMP), Monte Carmelo, MG, Brasil; E-mail: queirozz1981@yahoo.com.br

${ }^{* *}$ Doutorado em Direito Administrativo pela Universidade Federal de Minas Gerais (UFMG); Docente da Universidade Federal de Uberlândia (UFU) nos cursos de Graduação e Pós-Graduação, Brasil.
} 


\section{DERECHO FUNDAMENTAL AL ACCESO A LA JUSTICIA: CONTRADICTORIO COOPERATIVO COMO FORMA DE EXPRESIÓN DE LA EFECTIVA PRESTACIÓN JURISDICCIONAL}

RESUMEN: Ese trabajo, a partir de un análisis teórico-jurídico y práctico, buscará analizar el derecho fundamental al acceso a la justicia desde la perspectiva del contradictorio comparativo, de modo a obtener un posicionamiento sobre su importancia para la efectiva prestación jurisdiccional, en la medida que consagra el deber de efectivo dialogo de todos los participantes en el proceso - partes y magistrado - posibilitando, pues, que los litigantes influyan, de modo directo y inmediato, en la construcción de las decisiones judiciales, buscándose la efectiva pacificación de sus conflictos.

PALABRAS-CLAVE: Principio; Contradictorio; Cooperación; Prestación Jurisdiccional; Acceso a la Justicia.

\section{INTRODUÇÃO}

O direito, como conjunto de princípios, regras e valores que regulam a vida em sociedade, está presente onde quer que duas ou mais pessoas estabeleçam relação social. Partindo de um perfil marcantemente privado em sua origem, quando ainda se desconhecia o Estado como instituição dotada do prestígio hodierno, o direito, ao longo de seu desenvolvimento, passou a assumir natureza pública, ocupando-se dos fatos e conflitos das mais diversas áreas de interesse.

Nesse contexto, observa-se que a ciência do direito regula atividade que se encontra no cruzamento de problemas fundamentais da sociedade e do Estado, delineados na ideia de se fazer justiça e assegurar a integridade e vitalidade da ordem jurídica, frente à necessidade de se garantir as personalidades dos sujeitos nas suas recíprocas relações e em presença do poder social. Para tanto, deve oferecer os meios jurídicos para a defesa dos direitos e interesses e também da liberdade, que se exteriorizam no denominado processo judicial.

Com efeito, o processo constitui o instrumento de realização do direito material, cujo escopo traduz-se na ideia da pacificação social. Representa, pois, o método pelo qual se opera a jurisdição, a qual se resume no poder-dever do Estado de declarar e realizar o direito material. 
Dessa forma, o direito processual representa o complexo de princípios e regras que regulamentam e possibilitam o exercício da função jurisdicional pelo Estado, vale dizer, possibilita a atuação da vontade concreta do direito objetivo. Traduz-se, assim, como um direito instrumental, à medida que processo corresponde ao instrumento do direito material, sendo meio ético e político de atuação da justiça e de garantia da liberdade.

Nesse contexto, é possível constatar que a garantia da efetividade do processo constitui meio de concretização do direito fundamental ao acesso à justiça, o qual exige a universalização da tutela jurisdicional. Aliás, cumpre destacar que o fim precípuo do direito processual, e, por conseguinte, de sua trilogia estrutural jurisdição, ação e processo - é a realização e a garantia dos direitos fundamentais, por meio de organização e procedimentos próprios. Vale dizer, o direito processual deve encontrar seu fundamento de validade e eficácia nas normas de direito fundamentais.

Ocorre, porém, que a efetivação das garantias referidas no parágrafo anterior passa, sobretudo, pela observância de determinados princípios que, por seu turno, remetem-se à garantia do próprio acesso à justiça.

Nesse sentido, impende observar que não se deve entender o "acesso à justiça" como mero acesso ao Poder Judiciário, uma vez que, a princípio, o simples exercício do direito de ação não se revela, por si só, satisfatório para atingir o interesse daquele que almeja a tutela a ser proferida pelo Estado e, consequentemente, para se alcançar uma prestação jurisdicional justa.

O direito processual, portanto, deverá se posicionar na busca incessante pela efetivação do direito material, de maneira justa e equânime, o que se consolidará, sobretudo, pela compartição dos sujeitos atrelados a determinado processo, mediante observância dos fundamentos principiológicos, existentes na legislação em vigor.

Nesse contexto, o princípio do contraditório não foge à regra geral, por também ter suas delimitações histórico-sociais, não se mostrando, assim, indiferente às circunstâncias e valores da época em que foi exercido, revelando-se, dessa forma, essencial para o acesso material à justiça. Vale dizer, o princípio do contraditório passa, no atual estágio do direito processual, por uma releitura, que visa ultrapassar a sua concepção meramente formal - binômio informação-reação -, para abarcar o dever de efetivo diálogo ou a possibilidade de efetiva participação de todos os participantes no processo. 
Com efeito, o fato de o direito atrelar-se e adequar-se, constantemente, às mutações sociais, traz a necessidade de sua especialização, de forma a garantir a efetivação dos anseios das pessoas e possibilitar a concretização dos ditames do Estado democrático de Direito que, por sua vez, conforme exposto alhures, também ocorre com o amplo acesso à jurisdição.

Mediante tais adequações e necessidade de se permitir o acesso justo à prestação jurisdicional, surge o princípio da cooperação e, consequentemente, o princípio do contraditório cooperativo. $\mathrm{O}$ primeiro se remete ao pressuposto de que o direito processual encontra-se intimamente ligado à relação jurídica entre sujeitos processuais (juiz $\mathrm{x}$ parte e parte $\mathrm{x}$ parte), com o objetivo principal de composição justa do litígio mediante a participação de todos os envolvidos. Para tanto, desvincula-se do tecnicismo instituído pelas escolas processuais e se volta, também, às regras de conduta que, por sua vez, permitam compreender a finalidade social da norma procedimental.

No entanto, antes de se discorrer com a devida substanciação a respeito do contraditório cooperativo e, por decorrência, de sua influência na concretização do direito fundamental ao acesso à justiça, nota-se importante observar alguns preceitos, dentre os quais, sobreleva-se, ab initio, o fato de se tratar de um princípio processual constitucional.

\section{PRINCÍPIOS PROCESSUAIS CONSTITUCIONAIS}

Os princípios processuais constitucionais, em regra, encontram-se insculpidos no artigo $5^{\circ}$, da Constituição da República Federativa do Brasil de 1988, inserido dentro do Título dos Direitos e Garantias Fundamentais, o que, por si só, demonstra sua importância para o ordenamento jurídico.

Insta observar que os princípios constituem fontes primordiais para qualquer ramo científico, influindo tanto na formação quanto na aplicação de uma ciência. Vale dizer, "toda forma de conhecimento filosófico ou científico implica na existência de princípios". ${ }^{1}$

Nesse contexto, tem-se que a ciência jurídica é orientada e estruturada, dentre outros objetos, por princípios, sendo estes responsáveis pela legitimação da

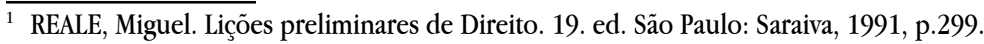


dogmática jurídica em um Estado democrático de Direito, por traduzir a essência, os valores que norteiam dado ordenamento. E, especificamente, no âmbito do direito processual, os princípios representam os preceitos fundamentais que atribuem forma e caráter aos institutos processuais.

Segundo Cândido Rangel Dinamarco:

A Constituição formula princípios, oferece garantias e impõe exigências, em relação ao sistema processual com um único objetivo final, que se como qualificar como garantia-síntese e é o acesso à justiça. Mediante esse conjunto de disposições ela que aperfeiçoar o processo a si mesma, de modo que ele reflita, em menor, o que em escala maior está à base do próprio Estado-de-direito. Ela quer um processo pluralista, de acesso universal, participativo, isonômico, liberal, transparente, conduzido com impessoalidade por agentes previamente definidos e observância das regras etc. - porque assim ela mesma exige que seja o próprio Estado e assim é o modelo político da democracia. ${ }^{2}$

A fim de se desenvolver um estudo sucinto e capcioso, é necessário averiguar, portanto, qual o significado do vocábulo princípios dentro do ordenamento jurídico.

Dessa feita, consoante ensinamentos de Miguel Reale, "os princípios são certos enunciados lógicos admitidos como condição ou base de validade das demais asserções que compõem dado campo do saber". ${ }^{3}$

Por sua vez, conforme leciona Humberto Ávila, in verbis:

Os princípios são normas imediatamente finalísticas, primariamente prospectivas e com pretensão de complementariedade e de parcialidade, para cuja aplicação se demanda uma avaliação da correlação entre o estado de coisas a ser promovido e os efeitos decorrentes da conduta havida como necessária à sua promoção. ${ }^{4}$

Dessa forma, verifica-se que os princípios são normas imediatamente finalísticas à medida que estabelecem um fim a ser atingido pela ordem jurídica, por meio da adoção de comportamentos necessários à sua efetivação. E não possuem pretensão de decidibilidade, mas sim de complementariedade, uma vez que, em conjunto com outras razões, servem de fundamento para a tomada de decisão.

${ }^{2}$ DINAMARCO, Cândido Rangel. Instituições de Direito Processual Civil. 6. ed. rev. e atual. São Paulo: Malheiros, 2009, v. 1, p.202-203.

3 REALE, Miguel. Lições preliminares de Direito. 19. ed. São Paulo: Saraiva, 1991, p. 300.

4 ÁVILA, Humberto. Teoria dos princípios:da definição à aplicação dos princípios jurídicos. 9. ed. São Paulo: Malheiros, 2008, p.78-79. 
Ademais, são normas de otimização que permitem e necessitam de ponderação, por estarem sempre em processo de concretização, pois não se constituem em regras prontas de comportamento.

Nesse contexto, tem-se que o direito processual corresponde ao complexo de princípios e regras jurídicas que regulamentam e possibilitam o exercício da função jurisdicional pelo Estado. Especificamente quanto aos princípios processuais, estes são responsáveis por informar e orientar a interpretação dos institutos do direito processual, visando garantir a efetivação do acesso à justiça, sendo que, por possuírem caráter prospectivo, determinam um estado de coisas a ser construído, influenciando, assim, a aplicação das regras processuais na concretização do direito material posto em questão no litígio apresentado diante do Estado-juiz.

Em vista disso, o texto constitucional vigente, visando buscar a concretização do direito fundamental ao acesso à justiça, consagra inúmeros princípios processuais que, em resumo, asseguram que a prestação jurisdicional seja efetiva, célere e adequada. Dentre referidos princípios, o devido processo legal representa o princípio dos princípios, ou seja, a origem e fundamento para todos os outros princípios processuais, previstos na ordem jurídica.

Aliás, cumpre asseverar que o princípio do devido processo legal, originado da expressão per legemterrae, utilizada na Magna Charta de 1215, revela-se de extrema relevância, pois, além de servir de esteio aos princípios constitucionais processuais, não se atrela, apenas, ao direito processual, mas à verdadeira adequação ao direito material.

Assim, o devido processo legal, em busca, primeiramente, de uma garantia individual, referida pelo artigo $5^{\circ}$, LV, da Constituição da República Federativa do Brasil de 1988, posiciona-se no sentido de que o Judiciário deverá perseguir, como objetivo precípuo de materialização do direito posto, a prestação jurisdicional, de forma que, presentes as devidas condições, atenda ao indivíduo e revele o direito a ser aplicado diante de determinado caso concreto.

Dessa forma, restringir o devido processo legal à mera tradução ou conceituações evasivas poderá ensejar em restrição indevida que, por seu turno, não revele o objetivo de proteção ampla ao indivíduo que possibilite desvendar caminhos para a consolidação efetiva do Estado democrático de Direito.

Nesse contexto, insta observar que, em decorrência do devido processo legal e da amplitude sociológica por ele almejada, identifica-se o princípio do contraditório. 
Contraditório, em linguagem simples, significa tudo aquilo que está em debate, que não é pacífico ou unânime, ou que traz, consigo, discórdia intrínseca.

Noâmbito da ciência processual, o contraditório inicia-se com a bilateralidade da relação processual, ainda que possa haver mais do que dois focos de interesse no processo.

Essa multiplicidade de interesses é, por óbvio, anterior ao processo. Trazidas à arena processual, as partes buscarão, por meio dos instrumentos que a lei lhes determinar, provar a supremacia de sua pretensão em oposição à parte contrária (e desfrutar do bônus dessa prova). Dentro do processo, as partes produzirão seu embate na disputa por um bem jurídico específico, com regras e instrumentos predeterminados. Esse combate deve ser assistido, fomentado e regido por um juiz, que, ao final, declarará o vencedor.

O contraditório e a garantia a ele relativa decorrem, portanto, da própria natureza da ação, que é, ela mesma, essencialmente bilateral.

Dentro dessa visão dualista, percebe-se a importância crucial do contraditório, até mesmo como legitimador do processo, haja vista que o Estado carreou para si a integralidade da função jurisdicional. A vedação da autotutela exige que se permita à parte usar todos os instrumentos (dentre os aceitos em um Estado democrático de Direito) para buscar o bem da vida pretendido, e a isso também se pode denominar de contraditório. Pretender algo diverso, ou seja, cercear, sem motivo justo, a atuação do indivíduo dentro do cenário jurídico, constituir-se-ia no maior dos óbices à pacificação social, ao invés de aproximá-la, ceifando, assim, o objetivo precípuo da ciência jurídica.

O princípio do contraditório é, portanto, uma garantia, não apenas para o indivíduo, ou mesmo para a sociedade, mas também para o próprio direito como instituição.

Pode-se dizer, portanto, que o contraditório carreia ao processo o mecanismo da dialética aristotélica: há uma tese, pretensão de cuja resistência surgirá a antítese. Plenamente informado por uma e outra, o órgão jurisdicional estará apto a prolatar uma síntese. Esta síntese, pelo menos em princípio, terá nesse mecanismo dialético uma das suas principais ferramentas na tentativa de atingir a pacificação social justa em qualquer campo de atuação jurisdicional. 


\section{O PRINCÍPIO DO CONTRADITÓRIO E SUA EXPRESSÃO COOPERATIVA COMO FORMA DE EFETIVIDADE DA PRESTAÇÃO JURISDICIONAL}

A Constituição Federal, pela importância jurídica e sociológica, assegura o contraditório, tanto no âmbito do direito processual civil, quanto no direito processual penal, ou mesmo no âmbito do direito administrativo. Aliás, nesse sentido é o disposto no inciso $\mathrm{LV}$, do artigo $5^{\circ}$, da Constituição vigente, in verbis: "aos litigantes, em processo judicial ou administrativo, e aos acusados em geral são assegurados o contraditório e ampla defesa, com os meios e os recursos a ela inerentes".

Quanto ao seu conceito, uma forma tradicional de definir o contraditório está na locução "paridade de armas". Essa paridade pode ser entendida como simultaneidade de oportunidades no processo, já que as oportunidades não podem ser concedidas às partes em momentos processuais diversos.

Dessa forma, observa-se que, a determinado ataque produzido sob a forma e no momento e previsto em lei, deve ser facultada a defesa de mesma intensidade em sentido contrário. Aqui se denota uma correlação fundamental entre contraditório, igualdade e ampla defesa.

O professor Gil Ferreira de Mesquita informa que

o contraditório presta-se justamente, de início, para a manutenção de processo como fenômeno dialético, necessário para que ambos os litigantes tenham no decorrer da atividade processual as mesmas condições para defesa de seus interesses, já que são sujeitos parciais da relação jurídica processual. ${ }^{6}$

Ademais, ainda com os ensinamentos do professor Gil, observa-se que

a participação das partes, considerados sujeitos parciais da relação jurídica processual, somente pode ser proporcionada com a tomada de conhecimento de todos os atos processuais praticados durante a atividade processual, sejam eles realizados pelo Estado (juiz e seus auxiliares), sejam eles realizados pelo adversário. ${ }^{7}$

Dessa forma, verifica-se que, em todas as definições do princípio do

5 BRASIL. Constituição da República Federativa do Brasil de 1988. Disponível em: < http://www.planalto.gov. br/ccivil_03/constituicao/constitui\%C3\%A7ao.htm >. Acesso em: 05 ago. 2015.

${ }^{6}$ MESQUTTA, Gil Ferreira de. Princípio do Contraditório e da Ampla Defesa no Processo Civil Brasileiro. São Paulo: Juarez de Oliveira, 2003, p.156.

Ibidem, 2003, p.158. 
contraditório, encontra-se o elemento "informação ao réu", seja no processo civil, seja no processo penal, compreendendo-se, pois, a necessidade de ser fornecida ao demandado a informação acerca da existência de um processo em seu desfavor, a fim de que se defenda. No âmbito civil, sendo os direitos disponíveis, em regra, o réu se defenderá se quiser; no âmbito penal, no entanto, por conta do interesse da sociedade, terá ele de ser defendido, queira ou não. Tão importante é esse elemento informação que existem autores que definem o contraditório com base nele e, concomitantemente, defendem que o juiz não pode, em hipótese alguma, julgar sem que tenha havido notícia ao demandado do processo que corre em seu desfavor. $^{8}$

Acerca do tema, vejam-se algumas decisões de tribunais brasileiros:

Ementa: APELAÇÃO. DIREITO PÚBLICO NÃO ESPECIFICADO. FORNECIMENTO DE ENERGIA ELÉTRICA. RESOLUÇÃO N. 456/2000 DA ANEEL. RECUPERAÇÃO DE CONSUMO NÃO MEDIDO. REVELIA. INOCORRÊNCIA. CONTESTAÇÃO PROTOCOLIZADA NO PRAZO LEGAL. VIOLAÇÃO AO CONTRADITÓRIO E À AMPLA DEFESA.Apresentada tempestivamente a contestação, descabido o reconhecimento da revelia, devendo ser desconstituída a sentença por cerceamento de defesa e violação ao princípio do contraditório, uma vez que o feito foi julgado de forma antecipada, sem que fosse oportunizada à parte demandada a produção de provas. Sentença desconstituída. SENTENÇA DESCONSTITUÍDA. (TJRS - Apelação Cível No 70063645287 , Vigésima Segunda Câmara Cível, Tribunal de Justiça do RS, Relator: Denise Oliveira Cezar, Julgado em 13/04/2015)

Ementa: APELAÇÃO CÍVEL Acidentária Sentença que extinguiu a execução, com fulcro no artigo 794, I, do Código de Processo Civil Inadmissibilidade Ausência de concordância expressa da obreira com o valor depositado para a satisfação do precatório Violação aos princípios da ampla defesa e do contraditório Extinção prematura Recurso provido para anular o processo a partir da sentença, inclusive, com retorno dos autos à origem, para que seja aberta oportunidade à apelante de se manifestar sobre a quantia paga pela autarquia. (TJSP - Apelação Cível n ${ }^{0}$ 0014514-63.2010.8.26.0565; Relator(a): Aldemar Silva; Comarca: São Caetano do Sul; Órgão julgador: $17^{\mathrm{a}}$ Câmara de Direito Público; Data do julgamento: 14/04/2015; Data de registro: $15 / 04 / 2015$ )

Ementa: DIREITO ADMINISTRATIVO E CONSTITUCIONAL. APELA-

${ }_{8}^{8}$ Em consonância com as definições expostas, Cintra, Grinover e Dinamarco afirmam ser imprescindível o conhecimento dos atos praticados pela parte contrária e pelo juiz, para que se possa estabelecer o contraditório. (ARAÚJO CINTRA, Antônio Carlos de; GRINOVER, Ada Pellegrini; DINAMARCO, Cândido Rangel. Teoria Geral do Processo. 17. ed. São Paulo: Malheiros, 2001, p.56) 
ÇÃO CÍVEL. SERVIDOR PÚBLICO ESTADUAL. PEDIDO DE PAGAMENTO DE ADICIONAL DE INSALUBRIDADE. LAUDO PERICIAL. AUSÊNCIA DE INTIMAÇÃO DAS PARTES PARA FORMULAR QUESITOS E INDICAR ASSISTENTES TÉCNICOS. AFRONTA AO DISPOSTO NO ARTIGO 431-A DO CÓDIGO DE PROCESSO CIVIL. OFENSA AO PRINCÍPIO DO CONTRADITÓRIO E DA AMPLA DEFESA. NECESSÁRIA REALIZAÇÃO DE NOVA PERÍCIA. RETORNO DOS AUTOS AO JUÍZO DE ORIGEM. PRECEDENTES DESTA CORTE. CONHECIMENTO E PROVIMENTO DO RECURSO. (TJRN - Apelação Cível ${ }^{\circ}$ 2012.010376-7; $3^{\text {a }}$ Câmara Cível, Relator: Des. Amaury Moura Sobrinho; Julgamento:13/11/2012)

Diante dessas considerações, é possível notar que o estabelecimento do contraditório e o exercício da ampla defesa se vinculam, essencialmente, ao fato de uma das partes ter ciência dos atos praticados pela parte contrária e pelo juiz da causa.

Entretanto, não se deve estreitar, sumariamente, o contraditório ao elemento da informação, razão pela qual o doutrinador Nelson Nery Junior define o contraditório com um caráter dúplice: por um lado, ele é a informação à parte da existência da ação, bem como de todos os atos do processo, e, de outro, a possibilidade de as partes se insurgirem contra os atos processuais que considerem desfavoráveis. Assim, conforme Nery Júnior, as partes devem ter a possibilidade "de deduzir suas pretensões e defesas, realizarem as provas que queiram para demonstrar a existência de seu direito, em suma, direito de serem ouvidas paritariamente no processo em todos os seus termos".

Tem-se, pois, que o princípio do contraditório não se presta apenas a dar ciência aos litigantes de todos os atos do processo, mas também para proporcionarlhes oportunidade de reagir contra quaisquer atitudes prejudiciais do juiz ou do adversário.

É fundamental que o contraditório seja garantido durante toda a relação processual. Dessa forma, pode-se entender como fundamental o contraditório na dilação probatória, mas não só nela: em tudo quanto houver manifestação das partes, o efetivo contraditório deve ser garantido; ou seja, não só no momento em que se tratar de prova, mas também em todas as manifestações das partes.

Deve-se observar, neste ponto, que há referência a todas as partes e não a ambas as partes, pois a bilateralidade do contraditório pode desdobrar-se em múltiplos focos de interesse, como ocorre nos casos de intervenção de terceiros.

9 NERY JUNIOR, Nelson. Princípios do Processo Civil na Constituição Federal. 3. ed. São Paulo: Revista dos Tribunais, 1996, p.133. 
Imagine-se o exemplo de processo em que ocorra oposição: haverá não duas, mas três partes, e todas rigorosamente em litigância entre si. Muito diverso de um caso de assistência, por exemplo, em que o terceiro é coadjuvante de uma das partes. E, mesmo sendo três os focos de interesse, é indispensável o respeito do contraditório a todos.

De qualquer forma, só há sentido em se cogitar a existência ou ausência do contraditório (processualmente considerado), quando haja exercício jurisdicional, e, nessa medida, se a jurisdição é pressuposto do contraditório, o inverso parece ser também verdadeiro. ${ }^{10}$

Estabelecidos, assim, os parâmetros básicos do princípio, cumpre, apenas, tentar avaliar a forma pela qual se deverá trazê-lo, de sua natural abstração, para a realidade do processo, e, dentro dessa realidade, instrumentalizar sua garantia constitucional.

Antes, porém, insta observar, conforme exposto alhures, que as constantes mudanças das relações sociais incidem, diretamente, nas bases teóricas da ciência jurídica e, precipuamente, no direito processual. Neste ponto, necessário vislumbrar que o princípio do contraditório deve se desvincular do conceito estrito de paridade de armas para se delinear como instrumento de efetiva participação das partes de determinada relação jurídica.

Rompe-se, assim, com o processo centralizador, arrimado, sobretudo na teoria desenvolvida por Oskar von Bülow que, por sua vez, instituiu o "processualismo" científico, voltando-se, porém, para a centralização da relação processual na figura do magistrado ${ }^{11}$, para a consolidação da comparticipação dos sujeitos processuais e do policentrismo processual, de forma a se estabelecer o contraditório cooperativo em busca de um processo democrático.

Nota-se, portanto, que o aludido processo democrático, consoante ensinamentos de Dierle Nunes, poderá

\footnotetext{
${ }^{10}$ Por conta do assinalado, observa-se que surgem, entre renomados doutrinadores (MEDINA, José Miguel Garcia; ARAÚJO, Fabio Caldas de; GAJARDONI, Fernando da Fonseca. Procedimentos cautelares e especiais. 4. ed. rev., atual. e ampl. São Paulo: Revista dos Tribunais, 2013, p.360), grandes divergências no que diz respeito à jurisdição voluntária em relação ao contraditório. O interesse processual, necessidade de jurisdição voluntária, decorre da lei, mas ainda assim o poder jurisdicional é invocado e praticado de maneira idêntica, tornando as diferenças entre as jurisdições voluntárias e contenciosas, meramente acidentais. Não cabe aqui aprofundar a análise da questão relativa à jurisdição voluntária; o fundamental, contudo, é constatar que, quaisquer que sejam os conceitos adotados a respeito dela, o contraditório está sempre presente. A fim de dirimir qualquer dúvida a esse respeito, basta imaginarmos as hipóteses em que a tutela jurisdicional pretendida não seja, por qualquer motivo, concedida, obrigando o requerente a recorrer e, consequentemente, demonstrar o equívoco do julgador, ou, ainda, que haja a intervenção do Ministério Público, pois, em qualquer dessas circunstâncias, haverá o contraditório.

${ }^{11}$ NUNES, Dierle José Coelho. Processo jurisdicional democrático. Curitiba: Juruá, 2011, p.99-101.
} 
Resgatar a importância do espaço público processual, no qual todos os interessados possam participar do aprimoramento do sistema jurídico, pode representar a tentativa de redescoberta da importância dessa estrutura normativa contra a indiferença e a apatia (coletiva) política na qual os cidadãos (clientes não participantes) estão imersos, e que são geradas pelo argumento dos "manipuladores olímpicos do poder" e pelos seus discursos tecnológicos de máxima eficácia prática e de diminuta repercussão social (cidadã) ${ }^{12}$

Destarte, o exercício da atividade jurisdicional ultrapassa a restrita concepção de declaração do direito, incumbindo ao magistrado promover a tutela concreta do direito material fundamental, por meio do efetivo diálogo com as partes. De fato, ao juiz cabe "atribuir sentido ao caso, definindo as suas necessidades concretas, para então buscar no sistema jurídico a regulação da situação que lhe foi apresentada, ainda que tudo isso obviamente deva ser feito sempre a partir da Constituição". ${ }^{13}$ Dessa forma, o Estado-juiz deve assumir posição presente no andamento processual, sem, contudo, romper com sua imparcialidade, mediante o constante diálogo com os litigantes, a quem deve ser assegurado participação ampla, dialética e isonômica durante a realização dos atos processuais, contribuindo eles, pois, para a construção do provimento final.

Nesse sentido, leciona Dierle, in verbis:

Ao magistrado cumpre, na alta modernidade, o papel democrático de garantidor dos direitos fundamentais, não podendo ser omisso em relação à realidade social e devendo assumir sua função institucional decisória num sistema de regras e princípios, embasado no debate endoprocessual, e no espaço público processual, no qual todos os sujeitos processuais e seus argumentos são considerados e influenciam a formação dos provimentos. ${ }^{14}$

Surge, então, em meio à necessidade de adequação do direito processual às mudanças e nuances sociais, o princípio da cooperação e, posteriormente, com a devida especificação, o princípio do contraditório em cooperação.

Busca-se, assim, o processo social que se desvincule da mera igualdade formal das partes e em que se desmistifica o protagonismo do magistrado, instituindo a comparticipação dos sujeitos de uma relação jurídica.

\footnotetext{
${ }^{12}$ Ibidem, 2011, p.251.

${ }^{13}$ MARINONI, Luiz Guilherme. Código de processo civil comentado artigo por artigo. São Paulo: Revista dos Tribunais, 2008, p.136.

${ }^{14}$ NUNES, Dierle José Coelho. Processo jurisdicional democrático. Curitiba: Juruá, 2011, p.256.
} 
Referida mutação processual que, por sua vez, institui-se, sobremaneira, pela cooperação entre os sujeitos da relação jurídica no desenvolvimento e resolução do litígio, encontra-se, inclusive, disciplinada na lei 13.105/2015 que estabeleceu o Novo Código de Processo Civil, especificamente, em seus artigos $5^{\circ}$ e $8^{\circ}$, confirmando, assim, a necessidade de se abarcar e desvelar o tema ora apresentado.

Diante da nova legislação, verifica-se que, no atual estágio do direito processual, passa-se por uma readequação do princípio do contraditório, de forma que o órgão jurisdicional se encontre no rol dos sujeitos processuais, dialogando e participando do processo, bem como as partes assumem posição de cooperação para com a atividade jurisdicional.

O princípio da cooperação estabelece, portanto, que o diálogo entre as partes, até então defendido, não se efetive, apenas, no âmbito da formalidade, mas, sobretudo, como instrumento de aperfeiçoamento da decisão judicial.

Observa-se, portanto, que a decisão judicial se torna consequência da atividade processual em cooperação, à medida que o instrumento procedimental é compartilhado. Ressalte-se, porém, que referida cooperação não extrai do magistrado, representante do Estado, o poder-dever de dizer o direito, pois referido ato revela-se consectário lógico do Estado de direito e do próprio devido processo legal.

Dessa forma, deve-se entender que o juiz em cooperação não deverá apenas conduzir o processo de maneira autoritária ou passiva, mas se valer da interação com as atividades produzidas pelas partes, a fim de se atingir o fim buscado pela atividade jurisdicional. Ressalte-se, entretanto, que a norma, como é apresentada, não extrai, por si só, o desequilíbrio existente na atuação do magistrado e dos demais envolvidos na relação processual, sendo, inclusive, questionável se referido padrão normativo não imiscuirá o juiz na perspectiva definitiva de autoritarismo na condução do procedimento perquirido. ${ }^{15}$

As partes, por seu turno, devem se posicionar em determinada relação processual, de forma a evitar prolongamentos e embaraços processuais desnecessários e fraudulentos, bem como discutirem acerca do gerenciamento realizado em determinado processo pelo juiz.

\footnotetext{
${ }_{15}$ Nesse sentido, STRECK, Lênio Luiz; DELFINO, Lúcio; DALLA BARBA, Rafael Giorgio; FERREIRA, Ziel Lopes. A cooperação processual do novo CPC é incompatível com a Constituição. Consultor Jurídico 2014. Disponível em: <http://www.conjur.com.br/2014-dez-23/cooperacao-processual-cpc-incompativel-constituicao $>$. Acesso em: 01 jan. 2016
} 
Contudo não se deve olvidar que esse dever de diálogo processual, imputado ao magistrado, faz com que surjam alguns questionamentos e problemáticas que devem ser enfrentados pelos juristas e pelo legislador. Com efeito, como deve ser vista a atuação do juiz quanto às matérias que podem ser conhecidas exofficio? Nesses casos, há a necessidade de se permitir às partes, previamente, apresentar suas manifestações sobre o tema para, só após, o juiz proferir sua decisão? O dever de prevenção atribuído ao magistrado - antevendo deficiências processuais na condução do processo pela parte, cabe ao juiz adverti-la do risco de não ser o direito material apreciado por questão puramente formal - não ocasionaria a substituição da atuação do advogado pelo Estado-Juiz? ${ }^{16}$

\section{CONSIDERAÇÕES FINAIS}

A concepção principiológica ora debatida ampara-se nas bases processuais do direito europeu, em que o interesse público se revela o principal foco para a resolução dos casos apresentados ao Poder Judiciário e, para tanto, deverá permearse pela cooperação de todos aqueles envolvidos na relação processual.

O magistrado, assim, perde a perspectiva de expectador e passa a desempenhar função primordial de colaboração na resolução da controvérsia. Todavia, apesar do destaque que o juiz passa a ter na análise e na busca da efetivação real do direito material, as partes se apresentam, ainda mais, como elementos essenciais no que se refere ao fornecimento de subsídios para que aquele possa proferir suas decisões com parcimônia e, sobretudo, amparado por elementos que legitimem o procedimento, de forma a se buscar fins sociais e não meramente perspectivas individuais.

É nesse sentido, portanto, que todos aqueles envolvidos na relação processual devem, cada vez mais, percorrer os caminhos da lealdade e boa-fé na consolidação dos atos processuais, a fim de se atingir uma administração hábil da justiça.

\footnotetext{
${ }^{16}$ Esse modelo caracteriza-se pelo redimensionamento do princípio do contraditório, com a inclusão do órgão jurisdicional no rol dos sujeitos do diálogo processual, e não mais como um mero espectador do duelo das partes. O contraditório volta a ser valorizado como instrumento indispensável ao aprimoramento da decisão judicial, e não apenas como uma regra formal que deveria ser observada para que a decisão fosse válida. A condução do processo deixa de ser determinada pela vontade das partes (marca do processo liberal dispositivo). Também não pode se afirmar que já uma condução inquisitorial do processo pelo órgão jurisdicional, em posição assimétrica em relação às partes. Busca-se uma condução cooperativa do processo, sem protagonismos." (DIDIER JR., Fredie. Fundamentos do Princípio da Cooperação no Direito Processual Civil Português. Lisboa: Coimbra, 2010, p.46-47).
} 
Ocorre, porém, que, a princípio, revela-se de extrema sensatez observar que o tema em análise não se reveste de absoluta originalidade, pois a cooperação entre as partes e a atuação do magistrado, com a devida parcimônia e sempre em busca da efetivação real do direito material, já se encontram devidamente delineadas na norma constitucional vigente, necessitando, apenas, da respectiva leitura teleológica e, na percepção de alguns, é, inclusive, incompatível (o que é incompatível?) com a norma constitucional, alegando para tanto que "as partes tem o direito de participar da decisão judicial (coisa pública), mas o juiz não pode intervir na defesa técnica de uma parte (coisa privada), senão para velar pelos mínimos limites assegurados à ação da contraparte". ${ }^{17}$

Diante da nova sistemática principiológica ora apresentada, resta observar que, mesmo se considerando as bases históricas e teóricas que defendem o liberalismo processual - protagonismo pleno das partes - e a socialização processual - protagonismo do juiz -esteios para o desenvolvimento do direito processual, bem como os entendimentos contrários e de extrema relevância, nota-se evidente que as mudanças das relações sociais exigem modificações da ciência jurídica e, no âmbito do processo, revela-se necessário proceder sua democratização por meio da comparticipação de todos os sujeitos da relação processual para se atingir os reais anseios e garantias constitucionais, notadamente, a concretização do direito fundamental ao acesso real à justiça.

\section{REFERÊNCIAS}

ARAÚJO CINTRA, Antônio Carlos de; GRINOVER, Ada Pellegrini; DINAMARCO, Cândido Rangel. Teoria geral do processo. 17. ed. São Paulo: Malheiros, 2001.

ÁVILA, Humberto. Teoria dos princípios:da definição à aplicação dos princípios jurídicos. 9. ed. São Paulo: Malheiros, 2008.

BRASIL. Constituição (1988). Constituição da República Federativa do Brasil. Brasília, DF: Senado Federal, 1988.

\footnotetext{
17 STRECK, Lênio Luiz; DELFINO, Lúcio; DALLA BARBA, Rafael Giorgio; FERREIRA, Ziel Lopes. A cooperação processual do novo CPC é incompatível com a Constituição. Consultor Jurídico 2014. Disponível em: $<$ http://www.conjur.com.br/2014-dez-23/cooperacao-processual-cpc-incompativel-constituicao $>$. Acesso em: 01 jan. 2016.
} 
DIDIER JR., Fredie. Curso de Direito Processual Civil. 7. ed. Salvador: JusPodivm, 2007. v.1.

DIDIER JR., Fredie. Fundamentos do princípio da cooperação no Direito Processual Civil Português. Lisboa: Coimbra, 2010.

DIDIER JR., Fredie. A instrumentalidade do processo. 14. ed. São Paulo: Malheiros, 2009.

DIDIER JR., Fredie. Instituições de Direito Processual Civil. São Paulo: Malheiros, 2011. v. 3.

DINAMARCO, Cândido Rangel. Instituições de Direito Processual Civil. 6. ed. rev. e atual. São Paulo: Malheiros, 2009. v. 1.

MARINONI, Luiz Guilherme. Código de processo civil comentado artigo por artigo. São Paulo: Revista dos Tribunais, 2008.

MARINONI, Luiz Guilherme. Teoria geral do processo. 6. ed. São Paulo: Revista dos Tribunais, 2012.

MARINONI, Luiz Guilherme. O projeto do CPC: crítica e propostas. São Paulo: Editora Revista dos Tribunais, 2010.

MESQUITA, Gil Ferreira de. Princípio do contraditório e da ampla defesa no Processo Civil Brasileiro. São Paulo: Juarez de Oliveira, 2003.

MEDINA, José Miguel Garcia; ARAÚJO, Fabio Caldas de; GAJARDONI, Fernando da Fonseca. Procedimentos cautelares e especiais. 4. ed. rev., atual. e ampl. São Paulo: Revista dos Tribunais, 2013.

MORAES, Alexandre de. Direito Constitucional. 15. ed. São Paulo: Atlas, 2004.

NERY JR., Nelson. Código de Processo Civil Comentado. São Paulo: Revista dos Tribunais, 2001.

NERY JR., Nelson. Princípios do Processo Civil na Constituição Federal. 3. ed. São Paulo: Revista dos Tribunais, 1996. 
NUNES, Dierle José Coelho. Processo jurisdicional democrático. Curitiba: Juruá, 2011.

PAMPLONA, Danielle Anne. Devido processo legal: aspecto material. Curitiba: Juruá, 2004.

PORTANOVA, Rui. Princípios do Processo Civil. 5. ed. Porto Alegre: Livraria do Advogado, 2003.

REALE, Miguel. Lições preliminares de Direito. 19. ed. São Paulo: Saraiva, 1991.

SANTOS, Ernane Fidélis dos. Manual de direito processual civil. 9. ed. São Paulo: Saraiva, 2003. v. 3.

SARMENTO, Daniel. A normatividade da Constituição e a constitucionalização do direito privado. Revista da EMERJ, v. 6, n. 23, p. 278-279, 2003.

SILVA, De Plácido e. Vocabulário Jurídico. 14.ed. Rio de Janeiro, Forense, 1998.

SILVA, José Afonso da. Curso de Direito Constitucional Positivo. 21. ed. São Paulo: Malheiros, 2002.

STRECK, Lênio Luiz; DELFINO, Lúcio; DALLA BARBA, Rafael Giorgio; FERREIRA, Ziel Lopes. A cooperação processual do novo CPC é incompatível com a Constituição. Consultor Jurídico 2014. Disponível em: < http://www.conjur.com.br/2014-dez-23/ cooperacao-processual-cpc-incompativel-constituicao > . Acesso em: 01 jan. 2016.

THEODORO JÚNIOR, Humberto. Curso de Direito Processual Civil. 38. ed. Rio de Janeiro: Forense, 2002. v. I.

Recebido em: 11 de agosto de 2015 Aceito em: 01 de fevereiro de 2016 